\title{
NILAI INDEKS GLIKEMIK PRODUK OLAHAN GEMBILI (Dioscorea esculenta)
}

\author{
(Glycemic Index Value of Dioscorea esculenta Product)
}

\author{
Rimbawan $^{1^{*}}$ dan Resita Nurbayani ${ }^{1}$
}

'Departemen Gizi Masyarakat, Fakultas Ekologi Manusia (FEMA), Institut Pertanian Bogor, Bogor 16680

\begin{abstract}
The objective of this research was to analyze the glycemic index values of gembili products. The research consisted of three stages covered: (1) processing of gembili into three treatments (boiled, steamed, and fried), (2) analyzing of nutrient contents in gembili products, (3) measuring of glycemic index of three processed food. Moisture content (wet based $/ \mathrm{wb}$ ) in boiled, steamed and fried gembili were $68.09 \%, 62.11 \%$, and $49.09 \%$ respectively. Ash content (dry based/db) in boiled, steamed and fried gembili were 1.62\%, $2.15 \%$, and $2.13 \%$ respectively. Fat content (dry based $/ d b$ ) were $0.63 \%, 0.37 \%$ and $7.75 \%$, while protein content (dry based $/ d b$ ) were $3.71 \%, 2.99 \%$, and $4.25 \%$. Insoluble dietary fiber content (dry based/db) between $11.79 \%$ to $13.43 \%$, while was higher than soluble dietary fiber content (dry based/db) between $5.84 \%$ to $10.88 \%$. Total dietary fiber content (dry based/db) in boiled, steamed and fried gembili were 19.01\%, 18.15\%, and 24.30\% respectively, while carbohydrate by difference content (dry based/db) were $91.05 \%, 93.33 \%$, and $88.88 \%$ respectively. The results of this study indicated that all glycemic index values of gembili products were high (>70). Glycemic index values gembili boiled, steamed, and fried gembili were 85.56, 87.56, and 83.61 respectively. Analysis of variance test One Way ANOVA showed that those treatments did not significantly affect the glycemic index value $(p>0.05)$
\end{abstract}

Keywords: gembili, glycemic index, nutrient contents

\begin{abstract}
ABSTRAK
Penelitian ini bertujuan untuk menganalisis nilai indeks glikemik produk olahan gembili (Dioscorea esculenta). Penelitian ini menggunakan desain penelitian experimental study. Tahapan penelitian ini terdiri dari: (1) proses pengolahan gembili menjadi gembili goreng, gembili kukus, dan gembili rebus, (2) analisis komposisi zat gizi gembili, (3) pengukuran indeks glikemik produk olahan gembili. Berdasarkan hasil analisis, kadar air (\%bb) pada gembili rebus, gembili kukus, dan gembili goreng masing-masing sebesar $68.09 \%$, 62.11\%, dan 49.09\%. Kadar abu (\%bk) pada ketiga jenis produk olahan gembili masing-masing sebesar $1.62 \%, 2.15 \%$ dan 2.13\%. Kadar lemak (\%bk) berkisar antara $0.37 \%$ sampai $7.75 \%$, sedangkan kadar protein (\%bk) berkisar antara 2.99\% sampai 4.25\%. Kadar serat pangan tidak larut (\%bk) masing-masing sebesar $13.17 \%, 11.79 \%$, dan $13.43 \%$. Kadar ini lebih tinggi dibandingkan kadar serat pangan larut (\%bk) sebesar 5.84\%, 6.37\%, dan 10.88\%, sehingga diperoleh kadar total serat pangan (\%bk) masing-masing sebesar $19.01 \%, 18.15 \%$, dan $24.30 \%$. Kadar karbohidrat sebesar $91.05 \%$, 93.33\%, dan $88.88 \%$. Hasil pengukuran respon glikemik individu menunjukkan bahwa nilai indeks glikemik produk olahan gembili tergolong tinggi (>70). Nilai indeks glikemik gembili rebus, gembili kukus, dan gembili goreng adalah 85.56, 87.56, dan 83.61. Uji sidik ragam One Way ANOVA menunjukkan bahwa perbedaan jenis pengolahan gembili tidak memengaruhi nilai indeks glikemiknya $(p>0.05)$.
\end{abstract}

Kata kunci: gembili, indeks glikemik, komposisi zat gizi

"Korespondensi: Departemen Gizi Masyarakat, Fakultas Ekologi Manusia (FEMA), Institut Pertanian Bogor, Bogor 16680. Email: rimbawan62@yahoo.com 


\section{PENDAHULUAN}

Menurut Riskesdas (2010) masalah obesitas cenderung terjadi pada kelompok dewasa di atas 18 tahun terutama pada masyarakat di perkotaan. Permasalahan yang terjadi dapat disebabkan karena konsumsi zat gizi (terutama karbohidrat dan lemak) yang tidak seimbang atau berlebihan. Selain itu, menurut Depkes (2009) masalah yang sering ditemui pada seorang atlet adalah kelelahan selama bertanding sehingga diperlukan pemenuhan kebutuhan energi yang cukup untuk proses pemulihan. Kedua permasalahan tersebut memerlukan metode yang tepat untuk pemilihan pangan terutama pangan sumber energi yaitu karbohidrat. Salah satu pendekatan dalam pemilihan pangan sumber karbohidrat adalah dengan menggunakan konsep indeks glikemik.

Konsep indeks glikemik dikembangkan untuk memberikan klasifikasi numerik pangan sumber karbohidrat. Makanan yang memiliki nilai indeks glikemik rendah dapat meningkatkan rasa kenyang dan menunda rasa lapar, sedangkan makanan yang memiliki nilai indeks glikemik tinggi mampu meningkatkan kadar glukosa darah dengan cepat (Aston 2006). Para ahli telah mempelajari faktor-faktor penyebab perbedaan indeks glikemik antara pangan yang satu dengan pangan yang lain.

Salah satu faktor yang memengaruhi indeks glikemik pangan adalah cara pengolahan (tingkat gelatinisasi pati dan ukuran partikel). Menurut Jenkins et al. (2002), proses pemasakan atau pengolahan membuat karbohidrat lebih mudah dicerna sehingga dapat meningkatkan nilai indeks glikemik, meskipun beberapa metode pengolahan, seperti parboilling, dapat menurunkan nilai indeks glikemik (Larsen et al. 2000). Oleh karena itu, penelitian pada beberapa jenis pangan dengan pengolahan berbeda-beda sangat diperlukan terutama pada beberapa jenis pangan lokal yang merupakan sumber karbohidrat yang memiliki potensi untuk diversifikasi pangan dan sebagai pangan fungsional di Indonesia seperti jenis umbi-umbian yaitu gembili.

Gembili merupakan tanaman yang dapat tumbuh di daerah beriklim tropis seperti Indonesia yang mudah dibudidayakan, mudah dikonsumsi dan dapat diolah menjadi berbagai produk olahan. Selain itu, gembili juga dapat dijadikan pangan fungsional karena mengandung inulin yang berfungsi sebagai prebiotik karena sebagai komponen serat pangan larut yang tidak dapat dicerna oleh enzim-enzim pencernaan, tetapi difermentasi oleh mikroflora kolon (usus besar) sehingga inulin dapat memperlancar proses pencernaan.

Akan tetapi, informasi mengenai potensi dari gembili masih sangat terbatas. Berdasarkan pertimbangan tersebut maka penulis tertarik untuk mempelajari pengaruh pengolahan terhadap nilai indeks glikemik pangan lokal yaitu gembili. Tujuan penelitian ini adalah mempelajari komposisi zat gizi, menganalisis nilai indeks glikemik produk olahan gembili, dan menganalisis pengaruh pengolahan terhadap nilai indeks glikemik produk olahan gembili (gembili rebus, gembili kukus, dan gembili goreng).

\section{METODE}

\section{Desain, Tempat, dan Waktu}

Desain yang digunakan dalam penelitian ini adalah studi eksperimental. Penelitian ini dilaksanakan selama tiga bulan, pada bulan September hingga Nopember 2012. Penelitian dilakukan di tiga lokasi yaitu Laboratorium Percobaan Pangan, Laboratorium Kimia dan Analisis Makanan, serta Klinik Gizi di Departemen Gizi Masyarakat, Fakultas Ekologi Manusia, IPB.

\section{Bahan dan Alat}

Bahan utama penelitian ini adalah gembili. Bahan kimia yang digunakan antara lain $\mathrm{NaOH}$, $\mathrm{HCl}$, dan etanol. Bahan yang digunakan untuk pengukuran respon glukosa darah pada subjek adalah sampel darah subjek dan glukosa murni ( $D$-glucose anhydrouse). Alat yang digunakan spektrofotometer UV-VIS dan Glucometer One Touch Ultra.

\section{Tahapan Penelitian}

Penelitian ini dilaksanakan dalam beberapa tahapan, diantaranya adalah tahap pengolahan gembili menjadi beberapa jenis produk olahan (gembili goreng, gembili kukus, dan gembili rebus). Setelah gembili diolah menjadi tiga produk olahan, tahapan selanjutnya adalah melakukan uji proksimat produk olahan meliputi analisis kadar air (metode oven biasa), protein (metode Kjedahl), lemak (metode ekstraksi Soxhlet), abu (metode pengabuan), karbohidrat (by difference), dan total serat makanan (metode enzimatis). Selain itu, dilakukan pula pengukuran tingkat gelatinisasi (metode IRRI) serta total pati yang diperoleh dari kadar amilosa (metode spektrofotometri) dan amilopektin (metode spektrofotometri). Jumlah porsi pangan acuan dan pangan uji yang diberikan kepada subjek setara dengan 25 g karbohidrat dan dengan tingkat kematangan yang homogen. Jumlah porsi yang diberikan kepada subjek untuk masing-masing produk olahan gembili disajikan pada Tabel 1.

Tahapan selanjutnya adalah perekrutan dan pemilihan subjek penelitian secara purposive yang memenuhi kriteria inklusi dan eksklusi. Kriteria inklusi dalam penelitian ini adalah subjek berumur 18-30 tahun baik pria atau wanita, memiliki indeks massa tubuh (IMT) normal $\left(18.5-22.9 \mathrm{~kg} / \mathrm{m}^{2}\right)$, dalam keadaan sehat, dan telah menandatangani informed consent. Kriteria eksklusi, subjek memiliki riwayat penyakit diabetes melitus, mengalami gangguan 
Tabel 1. Jumlah Porsi Gembili yang Diberikan kepada Subjek

\begin{tabular}{ccccc}
\hline Produk & $\begin{array}{c}\text { Carbohydrate by } \\
\text { Difference }(\% \mathrm{bb})\end{array}$ & Kadar Serat Total (\%bb) & Available Carbohydrate (\%bb) & Jumlah Porsi (g) \\
\hline Gembili rebus & 27.9 & 6.1 & 21.8 & 114.7 \\
Gembili kukus & 35.9 & 6.9 & 29.0 & 86.2 \\
Gembili goreng & 45.2 & 12.4 & 32.8 & 76.2 \\
\hline
\end{tabular}

pencernaan, menggunakan obat-obatan terlarang, meminum minuman beralkohol, dan merokok.

Setelah produk olahan pangan uji dan pangan acuan dikonsumsi oleh subjek penelitian, langkah selanjutnya adalah pengambilan sampel darah subjek untuk mengetahui indeks glikemik pangan uji. Menurut Miller et al. (1996) dalam Rimbawan \& Siagian (2004), prosedur penentuan indeks glikemik pangan adalah sebagai berikut: 1) Pangan acuan dan pangan uji dikonsumsi setara $25 \mathrm{~g}$ karbohidrat oleh subjek setelah menjalani puasa penuh kecuali minum air selama kurang lebih 10 jam. 2) Selama dua jam pasca pemberian pangan acuan, sampel darah sebanyak $50 \mu \mathrm{L}$ diambil dengan menggunakan fingerprick capillary blood samples method sebanyak dua kali secara berturut-turut pada menit ke 0 (sebelum pemberian), 15, 30, 45, 60, 90, dan 120 setelah pemberian pangan uji dan diambil rata-rata nilainya. 3) Pada waktu yang berlainan (7 hari kemudian) hal yang sama akan dilakukan dengan memberikan pangan uji ke-1 (gembili rebus), 7 hari berikutnya diberikan pangan uji ke-2 (gembili kukus), dan 7 hari berikutnya diberikan pangan uji ke-3 (gembili goreng) kepada subjek. 4) Kadar glukosa darah (pada setiap waktu pengambilan sampel) ditebar pada dua sumbu, yaitu sumbu x (waktu dalam menit) dan sumbu y (kadar glukosa darah). Kemudian kadar gula darah subjek diplotkan ke dalam grafik. 5) Indeks glikemik masing-masing subjek ditentukan dengan membandingkan luas daerah di bawah kurva antara pangan yang diukur indeks glikemiknya dengan pangan acuan.

\section{Pengolahan dan Analisis Data}

Perhitungan skor indeks glikemik dilakukan dengan menggunakan metode polinomial. Hasil yang diperoleh dari data tersebut adalah kurva respon glukosa darah individu dari pangan yang diuji. Pengujian hipotesa pengaruh pengolahan terhadap nilai indeks glikemik dianalisis menggunakan analisis sidik ragam (One Way ANOVA) dengan menggunakan software SPSS 16.0 .

\section{HASIL DAN PEMBAHASAN}

Subjek yang telah terkumpul dan memenuhi kriteria yang terdiri dari lima orang laki-laki dan lima orang perempuan diberikan pangan uji dan pangan acuan. Pangan uji berupa produk olahan gembili diantaranya gembili goreng, gembili kukus, dan gembili rebus. Pangan acuan yang digunakan adalah glukosa murni. Brouns et al. (2005) merekomendasikan pangan yang digunakan sebagai pangan acuan dalam penentuan nilai indeks glikemik yaitu glukosa murni untuk menjadikan nilai yang didapat lebih stabil.

\section{Komposisi Zat Gizi Produk Olahan Gembili}

Komposisi zat gizi produk olahan gembili disajikan dalam Tabel 2. Berdasarkan Tabel 2, kadar air tertinggi dari produk olahan gembili adalah gembili rebus karena pada proses pengolahannya menggunakan air. Kadar abu tertinggi adalah gembili goreng. Kadar lemak tertinggi adalah gembili goreng karena metode pengolahannya menggunakan media minyak

Tabel 2. Hasil Analisis Komposisi Zat Gizi Gembili Mentah, Rebus, Kukus, dan Goreng

\begin{tabular}{lcccc}
\hline \multicolumn{1}{c}{ Analisis Komposisi Zat Gizi } & Gembili Mentah & Gembili Rebus & Gembili Kukus & Gembili Goreng \\
\hline Kadar Air (\%) & 64.49 & 68.09 & 62.11 & 49.09 \\
Kadar Abu (\%bk) & 1.62 & 2.15 & 2.13 & 2.56 \\
Kadar Lemak (\%bk) & 0.51 & 0.63 & 0.37 & 7.75 \\
Kadar Protein (\%bk) & 4.63 & 3.71 & 2.99 & 4.25 \\
Carbohydrate by difference (\%bk) & 85.87 & 91.05 & 93.33 & 88.88 \\
Tingkat Gelatinisasi (\%bk) & 60.39 & 60.66 & 84.21 & 51.58 \\
Total Pati (\%bk) & - & 44.64 & 62.12 & 47.94 \\
Kadar Amilosa (\%bk) & - & 1.55 & 1.77 & 0.68 \\
Kadar Amilopektin (\%bk) & - & 43.08 & 60.36 & 47.26 \\
Kadar Serat (\%bk): & & & & \\
$\quad$ IDF & 18.43 & 13.17 & 11.79 & 13.43 \\
SDF & 5.77 & 5.84 & 6.37 & 10.88 \\
TF & 24.02 & 19.01 & 18.15 & 24.30 \\
\hline
\end{tabular}

JGP, Volume 8, Nomor 2, Juli 2013 
sebagai pengantar panas sehingga kemungkinan terjadi proses penyerapan minyak. Secara umum kadar protein dari produk olahan gembili tergolong rendah. Hal ini diduga karena protein telah berkurang akibat pemanasan suhu tinggi pada proses pengolahan. Carbohydrate by difference bertambah setelah melalui proses pengolahan. Hal ini dapat terjadi karena proses pengolahan menyebabkan beberapa zat gizi menjadi berkurang sehingga nilai carbohydrate by difference lebih tinggi.

Tingkat gelatinisasi terendah adalah gembili goreng. Hal ini diduga karena tingginya kadar serat dan lemak. Berdasarkan hasil analisis, proporsi amilopektin pada produk olahan gembili lebih besar dibandingkan kadar amilosanya. Secara keseluruhan kadar serat pangan tidak larut lebih tinggi dibandingkan serat pangan larut.

\section{Indeks Glikemik Produk Olahan Gembili}

Nilai indeks glikemik gembili rebus, gembili kukus, dan gembili goreng yang diperoleh dari ratarata nilai indeks glikemik sepuluh subjek penelitian disajikan pada Tabel 3. Berdasarkan Tabel 3 dapat dilihat bahwa nilai indeks glikemik produk olahan gembili memiliki selisih yang tidak besar. Selain itu, uji sidik ragam One Way ANOVA menunjukkan bahwa perbedaan jenis pengolahan gembili tidak memengaruhi nilai indeks glikemiknya $(p>0.05)$. Menurut Miller et al. (1996) dalam Rimbawan \& Siagian (2004), berdasarkan pengaruh glikemiknya, pangan dikelompokkan menjadi tiga kategori yaitu kategori pangan indeks glikemik rendah $(I G<55)$, indeks glikemik sedang $(I G=55-70)$, dan indeks glikemik tinggi (IG>70). Berdasarkan pengkategorian tersebut, dapat diketahui bahwa semua produk olahan gembili termasuk ke dalam kelompok pangan yang memiliki nilai indeks glikemik tinggi yaitu lebih dari 70 .

Tabel 3. Nilai Indeks Glikemik Produk Olahan Gembili

\begin{tabular}{cc}
\hline Sampel & Indeks Glikemik \\
\hline Gembili rebus & 85.56 \\
Gembili kukus & 87.56 \\
Gembili goreng & 83.61 \\
\hline
\end{tabular}

Menurut Jenkins et al. (2002), terdapat banyak faktor yang dapat menyebab perbedaan indeks glikemik antara pangan yang satu dengan pangan yang lain. Pangan dengan jenis yang sama pun dapat memiliki indeks glikemik berbeda bila diolah atau dimasak dengan cara yang berbeda. Faktor-faktor yang memengaruhi indeks glikemik pangan adalah cara pengolahan (tingkat gelatinisasi pati dan ukuran partikel), perbandingan amilosa dengan amilopektin, tingkat keasaman dan daya osmotik, kadar serat, kadar lemak dan protein, serta kadar anti gizi pangan. Proses pengolahan dapat menyebabkan nilai indeks glikemik pangan meningkat karena melalui proses pengolahan struktur pangan menjadi lebih mudah dicerna dan diserap sehingga dapat mengakibatkan kadar glukosa darah meningkat dengan cepat (Rimbawan \& Siagian 2004). Tingkat gelatinisasi memengaruhi nilai indeks glikemik karena proses gelatinisasi pati dapat menyebabkan granula pati mengembang. Granula yang mengembang dan molekul pati yang bebas sangat mudah dicerna karena enzim pencernaan di usus mendapat permukaan yang lebih luas untuk dapat kontak dengan molekul pati. Reaksi cepat dari enzim ini akan menyebabkan kadar glukosa darah meningkat cepat (Rimbawan \& Siagian 2004).

Hasil analisis tingkat gelatinisasi produk olahan gembili berdasarkan basis kering berkisar antara $51.58 \%$ sampai $84.21 \%$. Gembili kukus memiliki tingkat gelatinisasi tertinggi apabila dibandingkan dengan poduk olahan gembili lainnya. Hal ini diduga karena gembili kukus mengalami proses pemasakan dengan air dan panas yang dapat memperbesar ukuran granula pati. Pati yang terkandung pada gembili kukus mengalami lebih banyak gelatinisasi sehingga tingkat gelatinisasi gembili kukus tertinggi dibandingkan dengan produk olahan gembili lainnya. Oleh karena itu, gembili kukus tergelatinisasi penuh sehingga nilai indeks glikemiknya lebih tinggi dibandingkan produk olahan gembili lainnya.

Selain itu, gembili memiliki kandungan amilosa yang rendah dan kadar amilopektin yang tinggi. Hasil analisis kadar amilosa dan amilopektin pada produk olahan gembili menunjukkan kadar amilosa berdasarkan basis kering berkisar antara $0.68 \%$ sampai $1.77 \%$. Sedangkan kadar amilopektin berkisar antara $43.68 \%$ sampai $60.36 \%$. Secara umum, proporsi amilopektin pada produk olahan gembili lebih besar dibandingkan kadar amilosanya. Hal ini merupakan salah satu indikator bahwa gembili termasuk dalam pangan yang memiliki indeks glikemik tinggi.

Menurut Shanita et al. (2011) terdapat hubungan yang signifikan antara rasio amilosa dan amilopektin, dimana peningkatan kadar amilosa akan menurunkan nilai indeks glikemik. Amilosa dengan struktur yang tidak bercabang sehingga membuatnya terikat lebih kuat dan sulit untuk tergelatinisasi dan akibatnya sulit untuk dicerna. Amilopektin memiliki struktur bercabang dan memiliki ukuran molekul lebih besar dan lebih terbuka. Oleh karena itu, amilopektin lebih mudah tergelatinisasi dan akibatnya lebih mudah dicerna, sehingga bila suatu pangan memiliki kadar amilopektin yang lebih tinggi daripada kadar amilosa, respon glukosa darah lebih tinggi (Rimbawan \& Siagian 2004).

Komposisi zat gizi seperti lemak, protein, dan serat pangan juga memengaruhi nilai indeks glikemik. Lemak dalam makanan yang dikonsumsi akan memberikan rasa kenyang, karena lemak akan meninggalkan lambung secara lambat. Hal ini akan memperlambat waktu pengosongan lambung, se- 
hingga memperlambat timbulnya rasa lapar. Hasil analisis lemak menunjukkan bahwa gembili goreng memiliki kadar lemak yang tertinggi yaitu $7.75 \%$ apabila dibandingkan dengan produk olahan gembili lainnya yang berkisar antara $0.37 \%$ sampai $0.63 \%$, sehingga nilai indeks glikemik gembili goreng terendah dibandingkan dengan produk olahan gembili lainnya. Kadar lemak yang rendah diduga tidak berperan besar dalam memperlambat pengosongan lambung. Menurut Wolever dan Bolognesi (1996) lemak dalam jumlah yang besar (50 g lemak) dapat menurunkan respon glukosa darah dan respon insulin.

Hasil analisis protein menunjukkan bahwa kadar protein pada produk olahan gembili berdasarkan basis kering berkisar antara $2.99 \%$ sampai $4.63 \%$. Kadar protein produk olahan gembili relatif rendah. Menurut Mendosa (2008), penambahan protein terhadap karbohidrat dapat memperlambat proses penyerapan atau puncak dari respon glukosa. Namun menurut Rimbawan dan Siagian (2004), tidak semua pangan yang memiliki kadar protein tinggi, nilai indeks glikemiknya rendah. Menurut Chen et al. (2010) protein dan lemak pada makanan yang dikonsumsi pada umumnya tidak memengaruhi respon glikemik, sehingga pengaruh kadar protein terhadap nilai indeks glikemik diabaikan.

Serat pangan atau dietary fiber adalah karbohidrat (polisakarida) dan lignin yang tidak dapat dihidrolisis (dicerna) oleh enzim pencernaan manusia, dan akan sampai di usus besar (kolon) dalam keadaan utuh. Kandungan serat dapat memengaruhi nilai indeks glikemik karena dapat memperlambat respon glikemik. Pengaruh serat pada indeks glikemik pangan tergantung pada jenis seratnya, apabila masih utuh serat dapat bertindak sebagai penghambat fisik pada pencernaan. Akibatnya indeks glikemik cenderung lebih rendah (Araya 2002).

Hasil analisis kadar serat pangan pada produk olahan gembili berdasarkan basis kering menunjukkan bahwa gembili goreng memiliki kadar serat tertinggi yaitu $24.30 \%$ dibandingkan dengan gembili kukus yang sebesar $18.15 \%$ dan gembili rebus sebesar $19.01 \%$. Hasil penelitian ini berkaitan dengan kelima mekanisme efek hipoglikemik yang ditimbulkan oleh serat pangan. Oleh karena itu, nilai indeks glikemik gembili goreng lebih rendah apabila dibandingkan dengan nilai indeks glikemik produk olahan gembili lainnya.

Penelitian mengenai gembili masih sangat terbatas dan belum ditemukan literatur mengenai nilai indeks glikemik produk olahan gembili. Namun informasi mengenai nilai indeks glikemik produk olahan beberapa varietas umbi uwi disajikan pada Tabel 4. Berdasarkan Tabel 4 dapat dilihat bahwa terdapat banyak variasi nilai indeks glikemik dari umbi uwi dan gembili namun perbedaannya tidak terlalu besar, semua varietas masih tergolong memiliki nilai indeks glikemik yang tinggi. Variasi nilai indeks glikemik ini dapat disebabkan karena perbedaan varietas dan cara pengolahan yang diterapkan. Perbedaan komposisi zat gizi pada suatu pangan juga dapat berpengaruh terhadap respon glukosa darah.

Tabel 4. Nilai Indeks Glikemik Umbi Uwi

\begin{tabular}{lc}
\hline \multicolumn{1}{c}{ Pangan } & Nilai IG \\
\hline Gembili rebus & 85.56 \\
Gembili kukus & 87.56 \\
Gembili goreng & 83.61 \\
Gembili kukus (Marsono 2002) & 90 \\
Umbi uwi kuning panggang (Mendosa 2008) & $80 \pm 7$ \\
Umbi uwi putih panggang(Mendosa 2008) & $80 \pm 6$ \\
Umbi uwi putih rebus (Mendosa 2008) & $75 \pm 6$ \\
\hline
\end{tabular}

\section{KESIMPULAN}

Berbagai proses pengolahan menghasilkan komposisi zat gizi yang berbeda pada produk olahan gembili. Perbedaan komposisi zat gizi ini dapat disebabkan karena perbedaan proses pengolahan (rebus, kukus, dan goreng) meskipun dengan tingkat kematangan yang homogen, sehingga terdapat perbedaan respon glikemik pada masing-masing subjek penelitian. Hasil pengukuran respon glikemik menunjukkan bahwa setiap produk olahan memiliki respon glikemik yang berbeda meskipun selisihnya tidak besar. Nilai indeks glikemik produk olahan gembili tergolong tinggi (>70). Nilai indeks glikemik gembili rebus, gembili kukus, dan gembili goreng adalah 85.56, 87.56, dan 83.61. Hasil uji statistik menunjukkan bahwa perbedaan jenis pengolahan tidak memengaruhi nilai indeks glikemik ( $p>0.05$ ).

Nilai indeks glikemik produk olahan gembili tergolong tinggi sehingga diharapkan dapat menjadi panduan diet untuk menjaga kesehatan dan dapat direkomendasikan untuk individu atau kelompok yang membutuhkan energi dengan cepat diantaranya adalah untuk anak usia sekolah karena selain memiliki indeks glikemik yang tinggi, gembili memiliki kadar inulin yang cukup tinggi sehingga dapat berperan sebagai prebiotik dan mendukung proses pertumbuhan. Penelitian lebih lanjut mengenai nilai indeks glikemik produk olahan gembili ataupun varietas yang berbeda perlu dilakukan sehingga mempermudah dalam pemilihan pangan yang sesuai dengan kebutuhan.

\section{DAFTAR PUSTAKA}

Araya H. 2002. A comparison between an in vitro method to determine carbohydrate digestion rate and the glycemic response in young men. European Journal of Clinical Nutrition, 56, 735-739. 
Aston L. 2006. Glycemic index and metabolic disease risk. MRC Collaborative Centre for Human Nutrition Research, 65, 125-134.

Brouns F, Bjorck I, Frayn KN, Gibbs AL, Lang V, Slama G, \& Wolever TMS. 2005. Glycemic index methodology. Nutrition Research Reviews, 18, 145-171.

Chen YJ, Sun FH, Wong SH, \& Huang YJ. 2010. Glycemic index and glycemic load of selected Chinese traditional foods. World journal gastroentrology, 16(12), 1512-1517.

[Depkes] Departemen Kesehatan. 2009. Tahun 2030 prevalensi diabetes melitus di Indonesia mencapai 21.3 juta orang. www.depkes.go.id. [21 Mei 2012].

[Depkes] Departemen Kesehatan. 2010. Riskesdas 2010. Badan Penelitian dan Pengembangan Kesehatan, Jakarta.

Jenkins DJA, Kendall CWC, Augustin LSA, Franceschi S, Hamidi M, Marchie A, Jenkins AL, \& Axelsen M. 2002. Glycemic Index: overview of implica- tions in health and disease. Am. J. Clin. Nutr, 76, 266S-2735.

Larsen HN, Rasmussen OW, Rasmussen PH, Alstrup KK, Biswas SK, Tetens I, Thilsted SH \& Hermansen K. 2000. Glycemic index of parboiled rice depends on the severity of processing: study in type 2 diabetic subjects. European Journal of Clinical Nutrition, 54(5), 380-385.

Marsono Y. 2002. Indeks glikemik umbi-umbian. Agritech, 22, 13-16.

Mendosa. 2008. The glycemic index. www.mendosa. com/gi.htm [2 November 2012].

Rimbawan \& Siagian A. 2004. Indeks Glikemik Pangan. Penebar Swadaya, Jakarta.

Shanita SN, Hasnah H, \& Khoo CW. 2011. Amylose and amylopectin in selected Malaysian foods and its relationship to glycemic index. Sains Malaysiana, 40(80), 865-870.

Wolever TMS \& Bolognesi C. 1996. Source and amount of carbohydrate affect postprandial glucose and insulin in normal subjects. J Nutr, 126, 2798-806. 